\title{
熊本県天草地域におけるカメムシ類による温州ミカン幼果期の 加害が収穫期の果実品質に及ぼす影響
}

\author{
杉浦 直幸 ${ }^{1)}$. 古川 珠子 ${ }^{2)} \cdot$ 瀧崎 祥光 $^{21} \cdot$ 三角 正俊 ${ }^{2) *}$ \\ (1) 熊本県農業研究センター果樹研究所・2）熊本県農業研究センター天草農業研究所）
}

\begin{abstract}
Effect of stink bugs feeding on fruits in the young fruit stage on the fruit quality of Satsuma-mandarin at harvest in Amakusa, Kumamoto. Naoyuki Sugiura ${ }^{12}$, Tamako Furukawa ${ }^{21}$, Yoshimitsu Takizaki ${ }^{21}$ and Masatoshi Misumi ${ }^{2)}$ ( ${ }^{11}$ Fruit Tree Research Institute, Kumamoto Prefectural Agricultural Research Center, Uki, Kumamoto 869-0524, Japan. 2) Amakusa Agricultural Research Institute, Kumamoto Prefectural Agricultural Research Center, Amakusa, Kumamoto 863-0002. Japan)
\end{abstract}

2006年 5 月上旬から 8 月上旬にかけて熊本県天草地域に集中的に多飛来した果樹カメムシ類に よる温州ミカン幼果期の加害が, 収穫期の果実品質に及ほす影響を調查した。調査開始の 8 月 7 日から収穫日までの落果は，9月中旬の台風の通過直後にわずかに観察されたのみで，落下した 果実のカメムシ類による加害程度も比較的軽度であった。このことから，8月上旬までの加害で 落下しなかった果実の大多数は，収穫期まで樹上に残ると考えられた。カメムシ類による幼果期 の加害程度と収穫時の果実品質の関係を解析したところ, 加害による口針鞘数や剥皮不良箇所数 が增加するにつれて，「豊福早生」では着色遅延，糖度上昇，クエン酸含量の低下抑制が，「宮川 早生」ではクエン酸含量の低下抑制がみられる傾向にあった。

Key words : citric acid, coloring, Glaucias subpunctatus, Plautia crossota, sugar content

緒言

2006年 5 月上旬 $~ 8$ 月上旬にかけて，熊本県天草地域 において, チヤバネアオカメムシ Plautia crossota stali Scottやッヤアオカメムシ Glaucias subpunctatus (Walker) を主とする果樹カメムシ類がカンキツ園に大 量飛来し, 新梢の枯死や幼果の大量落下などの甚大な被 害を引き起こした。

熊本県農業研究センター天草農業研究所に設置した予 察灯（100W 高圧水銀灯）によるチヤバネアオカメムシ の誘殺消長は， 5 月上旬〜 8 月上旬までの期間， 5 月 4 半 句を除けば半旬当たり 1,000 頭以上で推移し，7月 6 半旬 には12,346頭のピークに達した。しかし，8月中旬以降 の誘殺数は一転して隇少傾向となり, 収穕期には極少発 生となった。こうした消長から，2006年のカンキッ類へ の加害は，幼果期に集中した状況になったと考えられる。

*現在 熊本県産業技術センター

*Present address : Kumamoto Industrial Reserch Institute, Higashimachi 3 -11-38. Kumamoto, Kumamoto 862 -0901, Japan
カメムシ類による加害が幼果期に集中した年として, これまで1992年や1996年の事例（磯田・行徳，1997；譨 林水産省果樹試験場, 1997）があるが, 県内の幼果期に 㧍けるカメムシ類の加害実態についての詳細な報告はな い。佐賀県では1996年の幼果期の集中加害について, 井 手ら（1997）が, 落果以外の被害の様相や, 収穫期まで 樹上に残った果実の品質について調查し、口針鞘が多く 残された果実ほど肥大や着色の達れ，また低糖高酸の傾 向を示すことを明らかにした。しかし，その後のカメム シ類の多発生年に扔ける定量的な再検証は殆どなされて いない。そこで本研究では，2006年に熊本県天草地域に おいて集中的に多飛来した果樹カメムシ類による幼果期 の加害が，収穫期の果実品質にどのような影響を及ほし たかを検討した。

\section{材料および方法}

\section{1. 調査園地および調査果実}

調查園地は熊本県農業研究センター天草農業研究所内 の温州ミカン園で, 極早生温州の「豊福早生」と早生温 州の「宮川早生」を各 2 樹供試した。当園地では2006年 
7 月下旬まで, チャバネアオカメムシとッヤアオカメム シを主とする果樹カメムシ類の多飛来が見られた。供試 樹から樹当たり 50 果, 各品種につき合計 100 果の果実と その結果枝に番号を付けて調査果とした。

調查内容は, 調查開始の 8 月 7 日から収穫日までの落 果状況と，収穫果実のカメムシ被害および品質であった。 調查果の収穫日は,「豊福早生」が10月11日，「宮川早 生」が11月21日で，各品種の収檴期に相当した。

\section{2. カメムシ類による被害状況と果実品質}

落下した果実は，落果日を記録して回収し，カメムシ によって形成された口針鞘と剥皮不良箇所を数え，果実 の横径を測定した。

収穫した果奏は，「豊福早生」では，口針鞘数，横径， 重量, 着色歩合を 10 月 12 日に，剥皮不良箇所数，糖度を 10月13日に，クエン酸含量を10月17日に測定し，「宮川 早生」では，横径，重量を11月22日に，口針鞘数，着色 歩合を11月24日に，剥皮不良箇所数，糖度を11月27日に， クエン酸含量を11月28日に測定した。

口針鞘数は実体顕微鏡下で計数し，剥皮不良筒所数は 果皮と果肉が剥がれにくくなっている部位を果皮を剥ぎ 取りながら数えた。着色歩合は JA 熊本果実連の出荷基 準に基づき，10段階評価で判別した（1〜10：数值が大 きいほど着色が良好となる)。果汁の糖度は(侏アタゴ製 のポケット糖度計, クエン酸含量は中和滴定法で測定し た。なお，肉眼で判断できる日焼け果については分析か ら除外した。

\section{3. カメムシ類による加害が果実品質に及ぼす影響の} 解析

カメムシ類による加害程度を示す指標となる口針鞘数 と剥皮不良筫所数を説明変数, 果実品質を示す指標を目 的変数として，カメムシ類による加害に対する果害品質 の回帰分析を行った。なお，果実品質の指標が横径，重 量, 糖度, クエン酸含量など連続変数の場合は単回帰分 析，離散変量の着色歩合の場合はロジット回帰分析 (SAS Institute, Inc., 2005) を行った。

\section{結 果および考察}

\section{1. 収穫前に落下した果実のカメムシ類による被害状 況}

収穫前に落果した果数は 3 果のみで，全て9月17日の 台風13号の通過直後に確認された。品種別にみると， 「豊福早生」では 1 果で, 口針鞘数は 3 本, 剥皮不良簤 所数は 2 䇢所, 横径は $55.2 \mathrm{~mm}$, 「宮川早生」では 2 果 で，口針鞘数はそれぞれ 12 本と 10 本，剥皮不良箇所数は 8 箇所と 3 箇所，横径は $58.3 \mathrm{~mm}$ と $55.8 \mathrm{~mm}$ であった。 落下した果実のカメムシ類による加害程度は比較的軽度 であった。以上のことから, 調査開始日の 8 月 7 日まで にカメムシ類の加害で早期落下しなかった果実は，被害 果のまま収穫期まで殆ど落下することなく樹上に残存し た。

\section{2. 収裇果に見られた被害状況と果実品質}

収穫果に見られたカメムシ類による被害状況と果実品 質について第 1 表，第 1 ～ 5 図に示した。「豊福早生」, 「宮川早生」ともに供試果実全てに扔いて，口針鞘が形 成されていた。「豊福早生」，「宮川早生」の口針鞘数の 平均 (土標準偏差) はそれぞれ29.0（ （土28.7）本で比較的ばらつきが大きかった（第 1 表）。 井手ら（1997）によると，1996年 7 月19日に，佐賀県内 のカメムシ類の多飛来園での口針鞘数を肉眼で観察した ところ,「上野早生」では口針鞘数が21～50個になるの が85果中 42 果，50個以上になるのが 85 果中 7 果，「大浦 早生」では21 50個になるのが87果中18果であったと報 告されている。また，熊本県天草地域のカメムシ類の多 飛来園で，2006年 7 月27日に早生温州ミカン「肥のあけ ほの」樹上の幼果30個を採集して調査したところ，口針 鞘数の平均 (土標準偏差 $)$ は30.2（土19.4）本であった (杉浦ら，未発表)。これらのことから，2006年も1996年 と同粎，7月頃をピークとしたカメムシ類による集中加 害を受けていたと推測される。本研究では，口針鞘数を 収權期に調查したため，幼果期に形成された口針鞘が部 分的に劣化や脱落している可能性も考えられる。しかし， 井手ら（1997）の報告によれば，口針鞘が多数残された 果実表面には凹状の変形が多く生じているため，その物 理的な形状によって口針鞘の磨耗が妨げられ，大部分の

第 1 表 収穫果のカメムシ類による被害状況と果実品質 ${ }^{2)}$

\begin{tabular}{cccccccrc}
\hline 供試品種 & 収檴日 & $\begin{array}{c}\text { 調查 } \\
\text { 果数 }\end{array}$ & 口針鞘数 & $\begin{array}{c}\text { 剥皮不良 } \\
\text { 筒所数 }\end{array}$ & 横径 $(\mathrm{mm})$ & 重量 $(\mathrm{g})$ & $\begin{array}{r}\text { 糖度 } \\
(\mathrm{Brix})\end{array}$ & $\begin{array}{r}\text { クエン酸 } \\
(\mathrm{g} / 100 \mathrm{ml})\end{array}$ \\
\hline 豊福早生 & $10 / 11$ & 71 & $29.0 \pm 22.6$ & $6.6 \pm 6.2$ & $68.6 \pm 5.3$ & $133.8 \pm 28.7$ & $9.5 \pm 0.5$ & $0.98 \pm 0.13$ \\
宮川早生 & $11 / 21$ & 63 & $43.4 \pm 28.7$ & $13.0 \pm 7.9$ & $77.1 \pm 6.7$ & $192.9 \pm 43.5$ & $11.1 \pm 0.6$ & $1.20 \pm 0.25$ \\
\hline
\end{tabular}

a) 数值は平均値土標準偏差. 
(A)

(B)

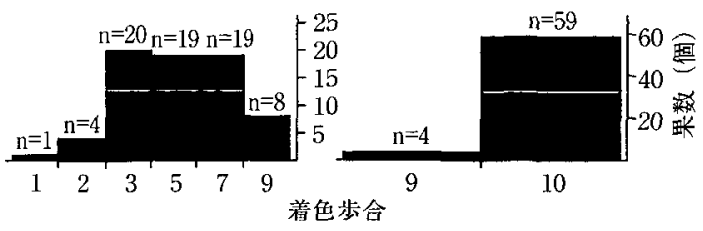

第 1 困収穫期に招ける果実の着色歩合.（A）豊 福早生. (B) 宮川早生. 着色歩合はJA 熊 本果実連の出荷基準に基づき10段階評価で判 别した（数值が大きいほど着色が良好）.
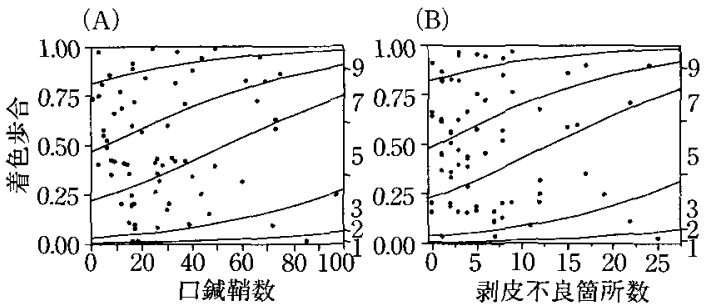

第 2図「豊福早生」における着色歩合と口針鞘数 （A）または剥皮不良簓所数（B）との関係。 着色歩合を目的変数として口針鞘数や剥皮不 良箇所数をロジット回帰分析.
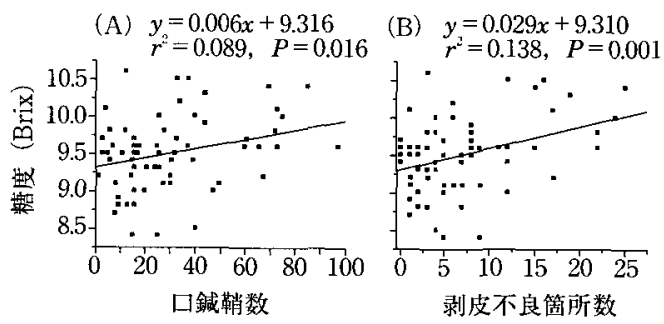

第 3 図「豊福早生」における糖度と口針鞘数 (A) または剥皮不良筒所数（B）との関係.

口針鞘が収穫期になっても十分確認できる状態で残され ていたことから，脱落による過小評価のリスクは小さい と思われる。

果実の着色歩合は, 極早生品種の「豊福早生」が 1 $3 ， 5 ， 7 ， 9$ と大きくばらついていたのに対し, 早生品種 の「宮川早生」では調查果の $93.7 \%$ が完全着色（着色歩 合10)となった（第 1 図）。この違いの一因として，「豊 福早生」は収穫適期よりやや早めに収穫され，「宮川早 生」は適期よりやや幄く収穫された可能性が考えられる。 「豊福早生」について，口針鞘数または剥皮不良箇所数

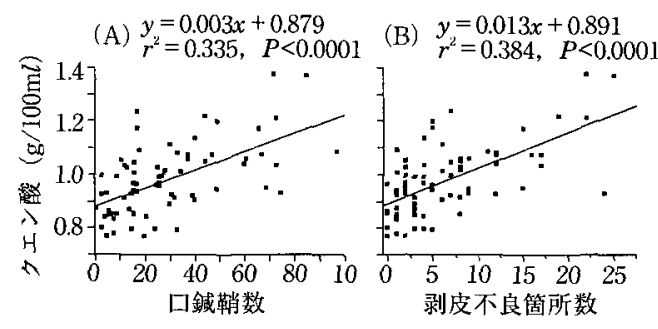

第4 図「豊福早生」におけるクエン酸含量と口針 鞘数（A）または剥皮不良箇所数（B）との 関係.

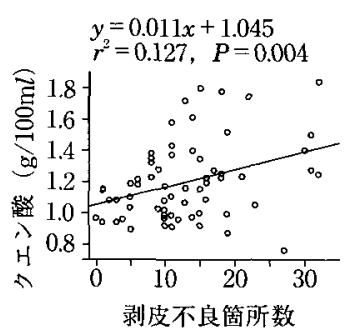

第 5 図「宮川早生」におけるクエン酸含量と剥皮 不良筒所数との関係。

に対する着色歩合のロジット回帰分析を行ったところ， 口針鞘数または剥皮不良箇所数の傾きは 0 より有意に大 きく（口針鞘数に対するロジット回帰分析：尤度比力イ 2 乗 $=5.69, P<0.05$, 剥皮不良箇所数に対するロジッ 卜回帰分析：尤度比力イ 2 乗 $=6.15, P<0.05$ ， 口針鞘 数または剥皮不良箅所数が多い活ど着色歩合が低下する 傾向が示された（第 2 図)。一方，「宮川早生」はほとん どの果実が完全着色であったため同様な傾向は䜑められ なかった。

カメムシ類による加害が果类重量に及ばす影響を調べ るため,「豊福早生」について果重と口針鞘数, 果重と 剥皮不良箇所数との相関を調べたところ，それぞれ有意 な正の相関がみられた（口針鞘数 $: r=0.39, P<0.05$ ； 剥皮不良箇所数： $r=0.27, P<0.05)$ 。同㥞に，「宮川 早生」についても同様な相関を調べたところ，それぞれ 有意な正の相関がみられた（口針鞘数： $r=0.38, P<$ 0.05 ; 剥皮不良箇所数 $: r=0.25, P<0.05)$ 。正の相関 が得られた一因として，相対的に大きな幼果ほどカメム シの加害を受けやすかったなどが考えられるが，相関の 寄与率は「豊福早生」で0.07と0.15,「宮川早生」で 0.06 と0.14といずれも低いため，収穫期まで残存した果 実で見る限りは，加害程度と果重の関係は小さいと思わ 
れる。

カメムシ類による加害が糖度に及ぼす影響を調べるた め,「豊福早生」について，口針鞘数または剥皮不良䈯 所数に対する糖度の单回帰分析を行ったところ，口針鞘 数または剥皮不良箇所数の傾きは 0 より有意に大きく, 口針鞘数や剥皮不良簓所数が多い注ど糖度が高くなる傾 向が示された（第 3 図）。しかし，「豊福早生」の糖度に 対する奇与率は0.09，0.14と低いことから，糖度に影響 を及ばす要因は他にもあると思われる。一方，「宮川早 生」については，同様な傾向は認められなかった。

カメムシ類による加害がクエン酸含量に及ぼす影響を 調べるため，「豊福早生」について，口針鞘数または剥 皮不良箇所数に対するクエン酸合量の単回帰分析を行っ たところ, 口針鞘数または剥皮不良筒所数の傾きは 0 よ り有意に大きく，口針鞘数や剥皮不良箇所数が多いほど クエン酸含量が高くなる傾向が示された（第 4 図）。ま た,「宮川早生」についても, 同様な単回帰分析を行っ たところ，口針鞘数では有意差は認められなかった（ $P$ >0.05）が, 剥皮不良箇所数では回州直線の傾きは 0 上 り有意に大きく, 剥皮不良箇所数が多いほどクエン酸含 量が高くなる傾向が示された（第 5 図）。

以上のことから，カメムシ類による加害程度が激しく， 口針鞘数や剥皮不良筒所数が増加するにつれて，「豊福 早生」では着色遅延, 糖度上昇, クエン酸含量の低下抑 制が,「宮川早生」ではクエン酸含量の低下抑制がみら れる傾向が示された。井手ら（1997）によると,「上野 早生」では口針鞘数が多いほど, 果重が小さく, 糖度が 低く, 着色が遅れ，「大浦早生」では果重が小さく，糖 度が低く、酸度が高く, 剥皮不良箇所が多くな更傾向が 見られた。したがって, 本研究と井手ら（1997）の結果 を比べると, 収穫果の着色遅延やクエン酸含量の低下抑 制については，対象品種の相違に関わらず共通した傾向
が認められたことから，他のカンキツ品種でも同様な現 象が見られる可能性があり，幼果期におけるカメムシ類 の加害を回避することの重要性を再認識させる結果と なった。一方，収穫果の果重や糖度については，本調査 と井手ら（1997）の結果は逆になった。また，本研究に おいて「宮川早生」の口針鞘数や剥皮不良箇所数が「豊 福早生」よりも1.50〜1.97倍多かったにも関わらず，タ エン酸含量以外では加害の影響が検出されなかった。こ れらの原因として，品種や熟期の相違が関与していると 思われるが，本研究でははっきりしたことは分からな かった。今後, 幼果期におけるカメムシ類の集中加害が, 果実品質を変質させるメカニズムの解明のみならず，収 量や樹体生理などに及ぼす影響の解明にも取り組むこと で，幼果期におけるカメムシ類の加害実態を総合的に把 握し, 防除要否の判断に結びつけてゆく必要がある。

\section{引用 文 献}

井手洋一・岩永秀人・安西 隆・末次信行・田代暢哉・ 松崎正文（1997）ウンシュウミカン幼果期における力 メムシ類の多飛来による果実被害. 九病虫研会報 $43: 110-113$.

磯田隆晴・行徳 裕（1997）熊本県における果樹力メム シ類のカンキツ幼果への集中飛来. 九病虫研会報 $43: 145$. (講要)

農林水産省果樹試験場（1997）「果樹カメムシ類異常大 発生に関する緊急調查研究」実施報告書. 農林水産省 果樹試験場 (つくば), pp. 36.

SAS Institute, Inc. (2005) JMP Version 6 Japanese edition. Cary, North Carolina, pp. 927.

(2007年5月 1 日受領 ; 8 月 2 日受理) 